\title{
KESADARAN HUKUM BERLALU LINTAS PENGEMUDI ANGKUTAN KOTA TRAYEK KODE E DI MAKASSAR
}

Oleh:

\author{
FIRMAN MUIN \\ SANTI
}

\section{Dosen PPKn FIS UNM}

\begin{abstract}
ABSTRAK: Penelitian ini bertujuan : 1) Untuk mengetahui kesadaran hukum berlalu lintas pengemudi angkot-trayek kode E di Makassar dan 2) Untuk mengetahui upaya kepolisian Negara Republik Indinesia- Polwiltabes Makassar dalam meningkatkan kesadaran hukum berlalu lintas pengemudi angkot-trayek kode E di Makassar. Untuk mencapai tujuan tersebut maka peneliti menggunakan teknik pengumpulan data melalui observasi, wawancara dan dokumentasi. Data yang telah diperoleh dari hasil penelitian diolah dengan menggunakan analisis deskriptif kualitatif untuk mengetahui kesadaran hukum berlalu lintas pengemudi angkot-trayek kode E di Makassar. Hasil penelitian menunjukkan bahwa :1) Kesadaran hukum berlalu lintas pengemudi angkot-trayek kode E di Makassar masih rendah diukur berdasarkan pengetahuan hukum, pemahaman hukum, sikap hukum dan perilaku hukum yaitu mereka sama sekali tidak mengetahui dan tidak memahami Undang-undang nomor 22 tahun 2009 tentang lalu lintas dan angkutan jalan akan tetapi mereka cenderung mengetahui dan memahami rambu-rambu lalu lintas, namun kurang menghargai dan kurang menaati peraturan tersebut, karena sudah menganggap pelanggaran sebagai kebiasaan, oleh karena itu dapat diketahui bahwa rendahnya kesadaran hukum cenderung karena pelanggaran jadi yang paling dominan mempengaruhi kesadaran hukum berlalu lintas pengemudi angkutan kota trayek kode E di Makassar yaitu perilaku. 2) upaya kepolisian Negara Republik IndinesiaPolwiltabes Makassar dalam meningkatkan kesadaran hukum berlalu lintas pengemudi angkutan kota di Makassar yaitu : a. upaya preventif yaitu, dalam rangka menanggulangi terjadinya pelanggaran lalu lintas di Kota Makassar pihak Satlantas Polrestabes Makassar melakukan upaya pencegahan dengan cara melakukan patrol-patroli rutin/oprasi rutin, menggelar razia kendaraan bermotor dan melaksanakan program peningkatan pengetahuan berlalu lintas dalam bentuk kegiatan : polisi sahabat anak, sosialisasi lintas universitas/police go to campus,keamanan berkendara, kampanye keselamatan lalu lintas, pembentukan organisasi terkait lalu lintas serta otomotif, KTL (Kawasan Tertib Lalu Lintas), sekolah mengemudi, dan lain-lain. Dan b.Upaya represif yaitu Tilang, apabila tindak pelanggarannya berat sehingga menimbulkan kecelakaan maka dapat pula diberikan sanksi berupa kurungan penjara sesuai UU Nomor 22 tahun 2009 tentang lalu lintas dan angkutan jalan.
\end{abstract}

\section{Kata Kunci: Kesadaran Hukum. Berlalu Lintas. Pengemudi Angkutan Kota Trayek Kode E}

ABSTRACT: This study aims: 1) To determine the legal awareness of traffic-route public transportation drivers in Makassar E code and 2) To determine the policing effort of the Republic Indinesia- Polwiltabes Makassar in raising legal awareness of traffic-route public transportation drivers in Makassar E code. To achieve these objectives, the researchers used a technique of collecting data through observation, interviews and documentation. Data have been obtained from the results of the study were processed using descriptive qualitative analysis to determine the legal awareness of traffic-route public transportation drivers in Makassar E code. The results showed that: 1) Awareness of the law-traffic public transportation drivers-stretch code E in Makassar still low measured based on legal knowledge, understanding of the law, the attitude of law and legal behavior that they did not know and did not understand the Act No. 22 of 2009 about traffic and 
road transport but they tend to know and understand the signs of traffic, but less appreciated and less obey the regulation, because it considers the breach as a habit, therefore it can be seen that the lack of legal awareness tends for violations so most The dominant influence of traffic law awareness of city transport drivers E in Makassar route code that behavior. 2) efforts to police the Republic Indinesia-Polwiltabes Makassar in raising awareness of traffic laws transport drivers in the city of Makassar, namely: a. preventive measures that, in order to tackle violations of traffic in the city of Makassar party Satlantas Polrestabes Makassar prevention efforts by conducting patrolroutine patrol / oprasi routine, held a raid of a motor vehicle and implement programs for improving knowledge of traffic in the form of activities: police friend to children, socialization crossuniversity / go to campus police, road safety, traffic safety campaign, the formation of trafficrelated organizations as well as the automotive, KTL (Region traffic Code), driving schools, and others. And b.Upaya Tilang repressive ie, if follow-heavy offense, causing an accident, it can also be given sanctions in the form of imprisonment in accordance with Law No. 22 of 2009 on traffic and road transport.

\section{Keywords: Legal Awareness. Traffic. The driver of the Municipal Transport Code Route E}

\section{PENDAHULUAN}

Negara Indonesia merupakan negara hukum yang telah diamanatkan Pasal 1 ayat 3 Undang-Undang Dasar Negara Republik Indonesia Tahun 1945, atas dasar tersebut segala tindakan masyarakat harus sesuai dengan hukum. Begitupun tindakan masyarakat di jalan raya harus sesuai dengan hukum sebagaimana telah diatur dalam Undang-Undang Nomor 22 Tahun 2009 tentang Lalu Lintas dan Angkutan Jalan, setiap pengguna jalan wajib memahami setiap aturan yang telah dibakukan secara formal baik dalam bentuk Undang-Undang dan aturan lainnya sehingga terdapat satu persepsi dalam pola tindak dan pola pikir dalam berinteraksi di jalan raya.

Jalan raya merupakan sistem sarana transportasi, khususnya transportasi darat. Sistem transportasi tersebut merupakan suatu hal yang penting untuk dimiliki oleh suatu kota, terutama kota besar yang memiliki banyak aktivitas dan banyak penduduk. Sistem transportasi merupakan hal krusial dalam menentukan keefektifan suatu kota. Pergerakan penduduk dan aktivitas ekonomi yang menggerakkan kota sangat tergantung pada sistem transportasi tersebut. Makassar merupakan salah satu kota besar di Indonesia, oleh karena itu sistem transportasinya merupakan hal yang penting. Salah satu sistem transportasi umum yang ada di Makassar adalah Angkutan Kota. Angkutan kota (angkot) sudah menjadi kebutuhan utama dalam mendukung kehidupan sehari-hari bagi sebagian besar masyarakat kota Makassar. Posisi angkutan kota yang menjadi kebutuhan utama ini menyebabkan banyaknya jumlah kendaraan angkutan kota di Kota Makassar. Namun hal tersebut ternyata tidak diiringi dengan adanya sikap tertib dalam berlalu lintas oleh sejumlah kendaraan angkotan kota di Kota Makassar.

Menurut data yang diperoleh dari Satlantas Polrestabes Makassar tahun 2016, dapat dilihat bahwa jumlah keseluruhan pelanggaran lalu lintas yang terjadi pada tahun 2015 berjumlah 1038 kasus merupakan pelanggaran yang dilakukan pengemudi angkutan kota. Jenis pelanggaran yang dilakukan meliputi pelanggaran dalam hal marka atau rambu lalu lintas, surat, dan perlengkapan kendaraan.

Hal tersebut didasari dengan kenyataan yang dihadapi di lapangan. Para sopir menunjukan adanya masalah dalam perilaku berlalu lintas. Mereka khususnya sering melakukan pelanggaran lalu lintas jalan. Dilihat dari masalah-masalah lalu lintas yang di lakukan oleh pengemudi angkot tersebut dapat diketahui bahwa salah satu problema hukum dewasa ini adalah kurangnya kesadaran pemakai jalan raya terhadap bahaya berlalu lintas dan masih rendahnya kesadaran hukum berlalu lintas masyarakat khususnya bagi pengemudi angkot. Akibatnya, banyak terjadi pelanggaran dan kecelakaan lalu lintas, Berdasarkan latar 
belakang diatas maka penulis tertarik untuk meneliti masalah tersebut dengan judul kesadaran hukum berlalu lintas pengemudi angkot-trayek kode E di Makassar (Studi di Wilayah Hukum Polrestabes Makassar).

Berdasarkan latar belakang maka tujuan penelitian ini adalah sebagai untuk mengetahui kesadaran hukum berlalu lintas pengemudi angkot-trayek kode E di Makassar. serta untuk mengetahui upaya yang dilakukan oleh aparat kepolisi RI- Polwiltabes Makassar dalam meningkatkan kesadaran hukum berlalu lintas pengemudi angkot trayek-kode E di Makassar

\section{TINJAUAN PUSTAKA}

\section{Kesadaran hukum}

\section{a. Pengertian kesadaran hukum}

Pengertian kesadaran hukum menurut para ahli :

a. Menurut Soerjono Soekanto, kesadaran hukum merupakan kesadaran atau nilanilai yang terdapat dalam diri manusia tentang hukum yang ada atau tentang hukum yang diharapkan ada. ${ }^{1}$

b. Menurut Sudikno Mertokusumo menyatakan bahwa kesadaran hukum berarti kesadaran tentang apa yang seyogyanya tidak kita lakukan atau perbuat terutama terhadap orang lain. Ini berarti kesadaran akan kewajiban hukum kita masing-masing terhadap orang lain. ${ }^{2}$

c. Menurut Paul Scholten, kesadaran hukum adalah kesadaran yang ada pada setiap manusia tentang apa hukum itu atau apa seharusnya hukum itu, suatu kategori tertentu dari hidup kejiwaan kita dengan mana kita membedakkan antara hukum dan tidak hukum, antara yang seyogyanya dilakukan dan tidak dilakukan. ${ }^{3}$

d. Ahmad Sanusi (1997), dalam batasan pengertian yang luas kesadaran hukum adalah potensi masyarakat yang harus membudaya dengan kaidah sehingga mengikat dan harus dipaksakan.

\footnotetext{
${ }^{1}$ Soerjono soekanto, 1982 kesadaran hukum dan kepatuhan hukum, Jakarta : cv. Rajawali, Hlm 152

${ }^{2}$ Sudikno mertokusumo, 1981, meningkatkan kesadaran hukum masyarakat, Yogyakarta : liberty, hlm 3

${ }^{3}$ Mertokusumo ,(1986), mengenal hukum suatu pengantar, Yogyakarta : liberty, hlm 2
}

e. Widjaya mengemukakan bahwa kesadaran hukum merupakan keadaan dimana tidak terdapatnya benturanbenturan hidup dalam masyarakat. Masyarakat dalam kehidupan seimbang, serasi dan selaras. Kesadaran hukum diterima sebagai kesadaran bukan diterima sebagai paksaan, walaupun ada pengekangan dari luar diri manusia atau masyarakat sendiri dalam bentuk perundang-undangan. ${ }^{4}$

Menurut Soerjono Soekanto, kesadaran hukum merupakan kesadaran atau nila-nilai yang terdapat dalam diri manusia tentang hukum yang ada atau tentang hukum yang diharapkan ada. $^{5}$

Indikator Kesadaran Hukum

a. pengetahuan hukum

Pengetahuan hukum adalah pengetahuan seseorang mengenai beberapa perilaku tertentu yang diatur oleh hukum. Sudah tentu hukum yang dimaksud di sini adalah hukum yang tertulis dan tidak tertulis. Pengetahuan tersebut erat kaitannya dengan perilaku yang dilarang ataupun perilaku yang diperbolehkan oleh hukum. Di samping itu, pengetahuan tersebut erat kaitannya dengan asumsi bahwa masyarakat dianggap mengetahui isi suatu peraturan manakala peraturan tersebut telah diundangkan.

b. pemahaman hukum

Pemahaman hukum diartikan sebagai sejumlah informasi yang dimiliki seseorang mengenai isi peraturan dari suatu hukum tertentu. Dengan kata lain, pemahaman hukum adalah suatu pengertian terhadap isi dan tujuan suatu peraturan dalam hukum tertentu serta manfaatnya bagi pihak-pihak yang yang kehidupannya di atur oleh peraturan tersebut. Dalam hal pemahaman hukum, tidak disyaratkan seseorang harus terlebih dahulu mengetahui adanya suatu aturan tertulis yang mengatur suatu hal. Akan tetapi yang dilihat disini adalah bagaimana persepsi mereka dalam

\footnotetext{
${ }^{4}$ A.W.widjaya (1984), kesadaran hukum manusia dan manusia pancasila. Jakarta : Era swasta.

${ }^{5}$ Soerjono soekanto, 1982 kesadaran hukum dan kepatuhan hukum, Jakarta : cv. Rajawali, Hlm 152

${ }^{6}$ Salaman (1993), beberapa aspek sosiologi hukum. Bandung : Alumni ,hal 40
} 
menghadapi berbagai hal yang ada kaitannya dengan norma-norma yang berlaku dimasyarakat. Pemahaman ini biasanya diwujudkan melalui sikap mereka terhadap tingkah laku sehari-hari. ${ }^{7}$

c. sikap hukum

Sikap hukum diartikan sebagai suatu kecenderungan untuk menerima hukum karena adanya penghargaan terhadap hukum sebagai sesuatu yang bermanfaat atau menguntungkan jika hukum itu ditaati. Suatu sikap hukum akan melibatkan pilihan masyarakat terhadap hukum yang sesuai nilai-nilai yang ada dalam dirinya sehingga akhirnya masyarakat menerima hukum berdasarkan penghargaan terhadapnya.

d.perilaku hukum

Pola perilaku hukum merupakan hal yang utama dalam kesadaran hukum, karena di sini dapat dilihat apakah suatu peraturan berlaku atau tidak dalam masyarakat. Dengan demikian sampai seberapa jauh kesadaran hukum dalam masyarakat dapat dilihat dari pola perilaku hukum. $^{8}$

\section{Peraturan lalu lintas dan angkutan jalan}

bermesin roda dua atau beroda empat pada umumnya dan kendaraan yang tidak bermesin contohnya sepeda, becak dan lain-lain.

Lalu Lintas dan Angkutan Jalan sebagai bagian dari sistem transportasi nasional harus dikembangkan potensi dan perannya untuk mewujudkan keamanan, keselamatan, ketertiban, dan kelancaran berlalu lintas dan Angkutan Jalan dalam rangka mendukung pembangunan ekonomi dan pengembangan wilayah. Undang-Undang Nomor 22 Tahun 2009 Tentang Lalu Lintas dan Angkutan Jalan adalah merupakan suatu dasar hukum terhadap pemberlakuan Kegiatan lalu lintas ini, dimana makin lama makin berkembang dan meningkat sejalan dengan perkembangan dan kebutuhan masyarakat yang terus meningkat. Kalau ditinjau lebih lanjut tingkah laku lalu lintas ini ternyata merupakan suatu hasil kerja gabungan antara manusia, kendaraan dan jaringan jalan.

\footnotetext{
${ }^{7}$ ibid ,hal 41

${ }^{8}$ Salaman (1993), beberapa aspek sosiologi hukum.

Bandung : alumni, hal 42
}

Lalu Lintas adalah gerak kendraan dan orang diruang lalu lintas jalan. ${ }^{9}$ Lalu Lintas dan Angkutan Jalan diselenggarakan dengan tujuan :

1) Terwujudnya pelayanan Lalu Lintas dan angkutan jalan yang aman, selamat, tertib, lancar, dan terpadu dengan moda angkutan lain untuk mendorong perekonomian nasional, memajukan kesejahteraan umum, memperkukuh persatuan dan kesatuan bangasa, serta mampu menjunjung tinggi martabat bangsa.

2) Terwujudnya etika berlalu lintas dan budaya bangsa.

3) Terwujudnya penegakan hukum dan kepastian hukum bagi masyarakat.

Lalu lintas adalah pergerakkan kendaraan, orang dan hewan di jalan. Pergerakkan tersebut dikendalikan oleh seseorang menggunakan akal sehat. Orang yang kurang akal sehatnya mengemudikan kenderaan dijalan, akan mengakibatkan bahaya bagi pemakai jalan yang lain. Demikian juga hewan dijalan tanpa dikendalikan oleh seseorang yang sehat akalnya akan membahayakan pemakai jalan yang lain. ${ }^{10}$

\section{a. Tata cara berlalu lintas antara lain :11}

\section{Ketertiban dan keselamatan}

a) Setiap orang yang menggunakan jalan wajib :

1) Berprilaku tertib dan / atau

2) Mencegah hal-hal yang dapat merintangi, membahayakan keamanan dan keselamatan lalu lintas dan angkutan jalan, atau yang dapat menimbulkan kerusakan jalan.

b). Setiap pengemudi kendraan bermotor dijalan wajib mematuhi ketentuan:

1) Rambu-rambu Lalu Lintas

2) Marka jalan

3) Alat Pemberi Isyarat

4) Gerakan Lalu Lintas

5) Berhenti dan Parkir

6) Peringatan dengan bunyi dan sinar. 
7) Kecepatan maksimal atau minimal; dan/atau

8) Tata cara penggandengan dan penempelan dengan kendraan lain.

c. Pada saat diadakan pemeriksaan kendraan bermotor dijalan penegemudi kendaraan bermotor wajib menunujukkan :
1) STNK atau STCK
2) SIM
3) Bukti lulus uji berkala;dan/atau
4) Tanda bukti lain yang sah

d. Setiap pengemudi kendraan bermotor roda empat atau lebih dijalan dan penumpang yang duduk disampingnya wajib mengenakan sabuk keselamatan.

e. Setiap pengemudi kendraan bermotor roda empat atau lebih yang tidak dilengkapi dengan rumah-rumah dijalan dan penumpang yang duduk disampingnya wajib mengenakan sabuk keselamatan dan mengenakan sabuk keselamatan dan mengenakan helm yang memenuhi standar Nasional Indonesia.

f. Setiap orang yang mengendarai dan penumpang sepeda motor wajib menegenakan helm yang memenuhi standar nasional Indonesia.

g. Pengendara sepeda motor tanpa kereta samping dilarang membawa penumpang lebih dari 1 (satu) Orang.

\section{METODE PENELITIAN}

\section{A. Pendekatan dan Jenis Penelitian}

1. Pendekatan penelitian

Adapun pendekatan yang digunakan dalam penelitian ini adalah pendekatan kualitatif. Menurut Nasution (1996 : 18) pada hakekatnya pendekatan kualitatif ialah mengamati orang dalam hidupnya, berinteraksi dengan mereka, berusaha memahami bahasa dan tafsiran mereka tentang dunia sekitar.

Penelitian ini menggunakan metode kuantitatif karena peneliti mempunyai tujuan untuk mendeskripsikan, menjelaskan, dan menggali informasi mengenai kesadaran hukum berlalu lintas pengemudi angkot-trayek kode E di Makassar.

2. Jenis penelitian

Dalam penelitian ini peneliti menggunakan jenis Penelitian sosioyuridis, yakni penelitian lapangan yang diperkuat dengan penelitian kepustakaan. Pengumpulan data dilakukan dengan cara wawancara yaitu mendatangi responden dengan melakukan Tanya jawab langsung, tipe pertanyaan teratur dan terstruktur ditujukan kepada pihak yang berkompeten. Serta data dapat pula berupa naskah, misalnya hasil rekaman wawancara, catatan-catatan lapangan, foto, video, dokumen pribadi, catatan atau memo dan dokumen resmi lainnya (Kaelan 2005: 20).

\section{B. Lokasi Penelitian}

Lokasi penelitian yang penulis pilih yakni pada kantor Polrestabes Makassar yang terletak di Jl. Ahmad Yani No.9 Kecamatan Makassar, kota Makassar, Sulawesi selatan.

\section{Deskripsi Fokus}

Untuk menghindari terjadinya persepsi yang keliru dan berlainan dalam penelitian ini, berikut ini akan dikemukakan definisis operasional yang dijadikan pegangan oleh peneliti dalam melakukan penelitian.

Definisi operasional dari penelitian dalam melakukan penelitian :

a. Kesadaran adalah keinsyafan atau merasa mengerti atau memahami segala sesuatu.

b. Hukum adalah peratuaran-peraturan yang bersifat memaksa, yang menentukan tingkah laku manusia dalam lingkungan masyarakat yang dibuat oleh badan-badan resmi yang berwajib, pelanggaran mana terhadap peraturan-peraturan tadi berakibatkan diambilnya tindakan, yaitu dengan hukuman tertentu.

c. Kesadaran hukum adalah pengetahuan bahawa perilaku tertentu diatur oleh hukum sehingga ada kecenderungan untuk mematuhi peraturan

d. Lalu lintas adalah gerak kendaraan dan orang di ruang lalu lintas jalan.

e. Pengemudi adalah orang yang mengemudikan kendaraan bermotor di jalan yang telah memiliki surat izin mengemudi

f. Angkutan kota (angkot) adalah sebuah moda transportasi perkotaan 
yang merujuk pada kendaraan umum dengan rute yang sudah ditentukan.

g. Trayek adalah izin resmi untuk mengoperasikan angkot sesuai dengan ketentuan dari DLLAJR (Dinas Lalu lintas Angkutan Jalan Raya). Angkot di kendarai oleh sopir pada jurusan tertentu pulang-pergi dengan menggunakan jalan raya pasti berdasarkan ketentuan yang berlaku di tempatkan oleh DLLAJR.

\section{Tahap-tahap Kegiatan Penelitian}

Ada 3 tahap dalam penelitian ini yaitu tahap perencanaan, pelaksanaan dan laporan penelitian.

1. Tahap Perencanaan

Langkah-langkah penelitian yang termasuk dalam perencanaa adalah :

a. Penentuan atau pemilihan masalah

b. Latar belakang

c. Perumusan masalah

d. Tujuan dan manfaat penelitian

e. Tinjauan pustaka dan kerangka konsep

f. Perumusan metode penelitian

Pada dasarnya hasil dari tahap perencanaan ini adalah rancangan penelitian yang sistematika penulisannya mencakup langkah diatas, penulisan rancangan rancangan penelitian harus:

a. Mencakup kegiatan yang akan dilakukan

b. Menuruti susunan yang sistematika dan logis

c. Membatasi hal-hal yang tidak diperlukan

d. Memperkirakan hasil yang akan dicapai.

2. Tahap Pelaksanaan

Dalam tahap pelaksanaan ada empat langkah yang harus dilakukan;

a. Pengumpulan data

b. Pengolahan data

c. Analisis data dan

d. Penafsiran hasil analisis

Kegiatan selanjutnya adalah melakukan tugas lapangan dalam rangka mengumpulkan data untuk kemudian
diproses.Proses inimeliputi penyuntingan, pengkodean, tabulasi, serta analisis sebagai dasar penarikan kesimpulan.

3. Tahap Penulisan Laporan Penelitian

Penulisan harus memperhatikan beberapa hal seperti : pembaca, bentuk dan isi, serta cara penyusunan laporan.

\section{E. Jenis dan Sumber Data}

Terdapat 2 (dua) jenis data yang diperlukan dalam penelitian ini yaitu:

1. Data Primer yaitu data dan informasi yang diperoleh secara langsung melalui wawancara dengan beberapa pengemudi angkutan kota dan Sat Lantas Polri yang bertugas di kota Makassar.

2. Data Sekunder yaitu data yang diperoleh dari berbagai sumber, seperti data yang diperoleh dari Kantor Polrestabes Makassar mengenai pelaksanaan penegakan hukum lalu lintas dan datadata yang juga diperoleh penulis pada berbagai literatur pada perpustakaan Universitas Negeri Makassar.

\section{F. Instrumen Penelitian}

Instrumen penelitian adalah alat bantu yang dipilih peneliti dalam kegiatan mengumpulkan data agar kegiatanya menjadi sistematis dan lebih mudah. Dalam penelitian Kualitatif teknik pengumpulan data yang utama adalah observasi dan wawancara, dalam prakteknya kedua metode tersebut dapat digunakan secara bersama-sama, artinya sambil wawancara juga melakukan observasi atau sebaliknya. Adapun instrumen yang dibuat peneliti, yaitu lembar observasi dan lembar pedoman wawancara.

Dalam observasi peneliti melakukan pengumpulan data dengan menyatakan terus terang kepada sumber data bahwa ia sedang melakukan penelitian. Jadi mereka yang diteliti mengetahui sejak awal sampai akhir tentang aktivitas peneliti. Observasi ini dimaksudkan untuk mengamati orang-orang dan juga kegiatan yang dilakukan dalam situasi sosial yang sedang berlangsung yaitu diantaranya melakukan observasi mengenai tempat dimana interaksi dalam situasi sosial sedang berlangsung. Aktor yaitu orang-orang yang terlibat dalam kegiatan yang tengah diteliti diantaranya pengemudi angkutan kota, aspek yang diamati antara lain 
mengenai kesadaran hukum pengemudi angkottrayek kode E di Makassar.

Pedoman wawancara merupakan pedoman yang digunakan selama proses wawancara yang berupa garis besar pertanyaan yang akan diajukan kepada subjek penelitian, yang bertujuan menggali informasi sebanyak banyaknya tentang apa, mengapa, dan bagaiman yang berkaitan dengan permasalahan yang diberikan.

Pertanyaan yang disiapkan berupa seperangkat pertanyaan baku dengan urutan pertanyaan, kata-kata dan penyajian yang sama untuk setiap subjek. Akan tetapi pertanyaan dalam wawancara dapat berkembang tanpa pedoman (bebas) tergantung jawaban awal setiap subjek. Sebelum penyusunan pedoman wawancara, dilakukan penyusunan kisi-kisi pedoman wawancara. Kisi-kisi pedoman wawancara disajikan pada lampiran.

\section{G. Prosedur Pengumpulan Data}

Suatu karya ilmiah membutuhkan sarana untuk menemukan dan mengetahui lebih mendalam mengenai gejala-gejala tertentu yang terjadi di masyarakat sebagai tindak lanjut dalam memperoleh data-data sebagaimana yang diharapkan, maka penulis melakukan teknik pengumpulan data yang berupa :

1. Observasi

Observasi adalah mengadakan pengamatan langsung di lapangan, yakni pengamatan tentang kesadaran hukum berlalu lintas pengemudi angkot-trayek kode E di Makassar

2. Wawancara.

Wawancara yaitu cara yang ditempuh untuk mengumpulkan data atau informasi dengan cara tanya jawab secara langsung untuk memperoleh gambaran tentang kesadaran hukum berlalu lintas pengemudi angkot trayek-kode E di Makassar.

3. Dokumentasi

Data-data yang didapatkan melalui dokumen, dokumentasi ini berisi data data yang berbentuk profil, file dan foto untuk memudahkan peneliti dalam mengumpulkan data tentang kesadaran hukum pengemudi angkot-trayek kode E di Makassar.

\section{H. Pengecekan Keabsahan Data}

Teknik keabsahan data yang digunakan dalam penelitian ini adalah teknik triangulasi sebagaimana dijelaskan oleh Sugiyono (2012), sebagai berikut:

1. Triangulasi Sumber

Triangulasi sumber dilakukan dengan cara mengecek data yang telah diperoleh melalui beberapa sumber. Dalam hal ini peneliti melakukan pengumpulan dan pengujian data yang telah diperoleh melalui hasil pengamatan, wawancara dan dokumen-dokumen yang ada.Kemudian peneliti membandingkan hasil pengamatan dengan wawancara, dan membandingkan hasil wawancara dengan dokumen yang ada.

2. Triangulasi Teknik

Triangulasi teknik dilakukan dengan cara mengecek data kepada sumber yang sama dengan teknik yang berbeda. Dalam hal ini data yang diperoleh dengan wawancara, lalu dicek dengan observasi dan dokumen.Apa bila dengan tiga teknik pengujian kredibilitas data tersebut, menghasilkan data yang berbeda-beda, maka peneliti melakukan diskusi lebih lanjut kepada sumber data yang bersangkutan atau yang lain, untuk memastikan data mana yang dianggap benar atau mungkin semuanya benar karena sudut pandangannya berbeda-beda.

3. Triangulasi Waktu

Waktu juga sering mempengaruhi kredibilitas data. Data yang dikumpulkan dengan teknik wawancara di pagi hari pada saat nara sumber masih segar, belum banyak masalah, akan memberikan data yang lebih valid sehingga lebih kredibel. Untuk itu dalam rangka pengujian kredibilitas data dapat dilakukan dengan cara melakukan pengecekan dengan wawancara, observasi atau teknik lain dalam waktu atau setuasi yang berbeda, maka dilakukan secara berulang-ulang sehingga sampai ditemukan kepastian datanya. Triangulasi dapat juga dilakukan dengan cara mengecek hasil penelitian, dari tim peneliti lain yang diberi tugas melakukan pengumpulan data.

\section{Analisis Data}

Data yang diperoleh baik primer maupun sekunder dianalisis secara kualitatif kemudian disajikan secara deskriptif yaitu menjelaskan, menguraikan, dan menggambarkan sesuai 
dengan permasalahan yang erat kaitannya dengan penelitian ini.

HASIL PENELITIAN DAN PEMBAHASAN PEMBAHASAN

1. Kesadaran hukum berlalu lintas pengemudi angkutan kota trayek kode $\mathrm{E}$ di Makassar

a. Pengetahuan Pengemudi Ankot Terhadap Rambu Lalu Lintas

Pengetahuan hukum merupakan faktor penting dalam mewujudkan kesadaran hukum berlalu lintas pengemudi khususnya pengemudi angkutan kota di kota Makassar, dengan adanya pengetahuan tersebut akan membantu mereka dalam kelancaran berlalu lintasnya.

Berdasarkan hasil wawancara diatas dapat disimpulkan bahwa pengetahuan sopir angkot khususnya jalur trayek kode E, Makassar Mall UNM - Perumnas Panakukang terhadap jenis-jenis rambu lalu lintas dijalan raya pada umumnya mereka telah mengetahui jenis-jenis rambu lalu lintas, jenis-jenis rambu lalu lintas yang dimaksud yaitu : rambu peringatan, rambu larangan, rambu petunjuk, rambu perintah, lampu isyarat, rambu tambahan, rambu nomor rute, dan marka jalan . Namun pengemudi angkot kurang mengetahui tentang undangundang nomor 22 tahun 2009 tentang lalu lintas dan angkutan jalan, akan tetapi mereka dianggap mengetahui ketika undang-undang tersebut telah diundangkan. Tata cara berlalu lintas bagi pengemudi kendaraan bermotor umum angkutan orang yang sesuai dengan Undang-undang Nomor 22 tahun 2009,pada pasal 124 ayat 1 dan 2 yaitu :

(1) Pengemudi kendaraan bermotor umum untuk angkutan orang dalam trayek wajib :

a. Mengangkut penumpang yang membayar sesuai dengan tarif yang telah ditetapkan ; b. Memindahkan penumpang dalam perjalanan kekendaraan lain yang sejenis dalam trayek yang sama tanpa dipungut biaya tambahan jika kendaraan mogok, rusak, kecelakaan, atau atas perintah petugas;

c. Menggunakan lajur jalan yang telah ditentukan atau menggunakaan lajur paling kiri, kecuali saat akan mendahului atau mengubah arah;

d. Memberhentikan kendaraan selama menaikkan dan/atau menurunkan penumpang;

e. Menutup pintu selama kendaraan berjalan; dan

f. Mematuhi batas kecepatan paling tinggi untuk angkutan umum.

(2) Pengemudi kendaraan bermotor umum untuk angkutan orang dalam trayek dengan tariff ekonomi wajib mengangkut anak sekolah

Adapun faktor pendukung pengetahuan pengemudi angkot mengenai tata tertib berlalu lintas sopir angkutan mikrolet Makassar Mall UNM - Perumnas Panakukang yaitu pengetahuan yang diperoleh dari berbagai sumber informasi, peranan petugas dan peraturan sarana jalan, hukum dan undang-undang lalu lintas, serta kesadaraan dan keikutsertaan pengemudi dalam ujian penalaran pelaksanaan tata tertib berlalu lintas. Pengetahuan pengemudi tentang tertib berlalu lintas dapat diperoleh dari berbagai sumber informasi,seperti media massa, media sosial, sekolah, teman, kegiatan pendidikan masyarakat (Dikmas), dan penataran mengemudi atau pendidikan dan latihan mengemudi (Diklat).

b. Pemahaman Pengemudi Angkot Terhadap Rambu Lalu Lintas

Pemahaman hukum diartikan sebagai sejumlah informasi yang dimiliki seseorang mengenai isi peraturan dari suatu hukum tertentu. Dengan kata lain, pemahaman hukum adalah suatu pengertian terhadap isi dan tujuan suatu 
peraturan dalam hukum serta manfaatnya bagi pihak-pihak yang kehidupannya diatur oleh peraturan tersebut. Dalam hal pemahaman hukum tidak disyaratkan seseorang harus terlebih dahulu mengetahui adanya suatu aturan tertulis yang mengatur suatu hal, akan tetapi yang dilihat disini adalah bagaimana persepsi mereka dalam menghadapi berbagai hal yang ada kaitannya dengan norma-norma yang berlaku di masyarakat. Pemahaman ini biasanya diwujudkan melalui sikap dan tingkah laku.

Berdasarkan wawancara dengan beberapa pengemudi dapat disimpulkan bahwa mayoritas pengemudi angkot khususnya trayek Makassar Mall-UNMP.Panakukang memahami isi dan tujuan dari beberapa rambu lalu lintas, akan tetapi kurang paham terhadap isi dari undang-undang nomor 22 tahun 2009 sebagai undang-undang yang mengatur tentang lalu lintas dan angkutan jalan.

\section{c. Sikap Pengemudi Angkot Terhadap Tata Tertib Lalu Lintas}

Sikap hukum sebagai suatu kecenderungan untuk menerima hukum karena adanya penghargaan terhadap hukum sebagai suatu yang bermanfaat atau menguntungkan jika hukum itu di taati, jika semua pengemudi angkot khususnya trayek kode E Makassar Mall- UNM- P.Panakukang dapat menerima, menghargai dan mentaati setiap aturan dalam berinteraksi di jalan raya, maka itu sangat menguntungkan karena dapat menciptakan keamanan dan ketertiban di jalan raya.

Sikap taat berarti tunduk atau patuh atas suatu ketentuan. Sikap taat diwujudkan dalam kemauan untuk menjalankan perintah dan menjauhi larangan khususnya di jalan raya. Dengan demikian, sikap taat terhadap tata tertib berlalu lintas adalah tunduk dan patuh terhadap segala aturan yang telah diberlakukan dengan memenuhi kewajiban yang dibebankan dan tidak melanggar hal-hal yang dilarang.
Mematuhi peraturan lalu lintas, seperti berkendara di lajur yang benar, tidak menerobos lampu merah, tidak melanggar rambu larangan, memakai atribut keselamatan berkendara, mengutamakan keselamatan pejalan kaki,dan sebagainya.

Berdasarkan dari hasil wawancara dapat diketahui bahwa pengemudi angkot khususnya trayek kode E Makassar Mall- UNM-P.Panakukang cenderung menerima namun kurang menghargai aturan lalu lintas dijalan raya.

Dan dalam menjalankan aturan tata tertib berlalintas pastinya harus memiliki fasilitas pendukung penyelenggaran lalu lintas dan angkutan jalan meliputi trotoar , lajur sepeda, tempat penyebrang pejalan kaki, halte, dan fasilitas khususnya bagi penyandang cacat dan manusia usia lanjut.

d. Perilaku Pengemudi Angkot Terhadap Tata Tertib Lalu Lintas

Kepatuhan sangat di perlukan bagi para pengemudi angkutan kota untuk menciptakan kenyamanan dalam berlalu lintas. Untuk mengukur apakah sopir angkot patuh atau tidak dapat dilihat dari aturan berlalu lintasnya, apakah sopir menjalankan aturan tersebut atau tidak.

Setiap orang yang mengemudikan kendaraan bermotor di jalan wajib mematuhi ketentuan :

a) Rambu perintah atau rambu larangan

b) Marka jalan

c) Alat pemberi isyarat lalu lintas

d) Gerakan lalu lintas

e) Berhenti dan parkir

f) Peringatan dengan bunyi dan sinar

g) Kecepatan maksimal atau minimal

h) Tata cara penggandengan atau penempelan dengan kendaraan lain.

Dari hasil wawancara dan observasi diatas dapat diketahui bahwa jenis-jenis pelanggaran yang dilakukan oleh pengemudi angkot khususnya 
pengemudi angkot trayek kode $\mathrm{E}$ di Makassar yaitu :

1. Rambu lalu lintas (paling sering dilanggar adalah rambu larangan)

2. Surat-surat/ SIM

3. Kecepatan

4. Marka jalan

Untuk menciptakan ketertiban dan keselamatan,setiap orang yang menggunakan jalan wajib :

a) Berperilaku tertib, dan

b) Mencegah hal-hal yang dapat merintangi, membahayakan keamanan dan keselamatan lalu lintas dan angkutan jalan, atau dapat menimbulkan kerusakan jalan

Berdasarkan hasil wawancara diatas dapat diketahui bahwa pengemudi angkot khususnya trayek kode E Makassar Mall-UNMP.Panakukang melakukan pelanggaran dengan beberapa alasan yaitu:

1. Mengejar setoran

2. Tidak ada polisi

3. Terpaksa karena yang lain melanggar

4. Tidak paham rambu lalu lintas

Namun dapat diketahui bahwa yang paling dominan dengan alasan mengejar setoran, sebagaimana yang dikemukakan oleh soerjono soekanto bahwa ketidak patuhan terhadap hukum disebabkan oleh : pelanggaran hukum oleh sipelanggar sudah dianggap sebagai kebiasaan bahkan kebutuhan.

Dari hasil penelitian saya juga berbeda dengan pemaparan Durkhem menyatakan bahwa bersanksi yang berat - ringannya tergantung pada sifat pelanggaran, dan itu sangat berbeda dengan hasil penelitaian saya karena kebanyakan responden - responden yang saya wawancarai mengungkapkan bahwa sanksi yang diberikan oleh polisi lebih ringan dibandingkan dengan semestinya. Seperti lebih dimudahkan dalam proses hukum (Bayar di tempat), dan tidak sesuai dengan ketentuan berlaku.
Ketidak patuhan terhadap hukum dapat disebabkan oleh dua hal, yaitu:

a) Pelanggaran hukum oleh si pelanggar sudah dianggap sebagai kebiasaan bahkan kebutuhan;

b) Hukum yang berlaku sudah tidak sesuai lagi dengan tuntutan kehidupan.

Pendapat Paul Scholten ini dipertegas oleh pendapat Soerjono Soekanto yang mengemukakn bahwa "kesadaran hukum sebenarnya merupakan kesadaran atau nilai-nilai yang terdapat di dalam diri manusia tentang hukum yang ada atau tentang hukum yang diharapkan".

Sangat penting bagi pengemudi khususnya pengemudi angkot untuk mengetahui, memahami dan mematuhi aturan berlalu lintas agar tercipta keamanan, keselamatan, dan ketertiban di jalan raya.

2.Upaya Kepolisian RI-Polwiltabes Makassar Dalam Meningkatkan Kesadaran Hukum Pengemudi Angkot-trayek kode E di Makassar

Ada dua upaya yang dilakukan oleh Sat lantas polrestabes makassar dalam menanggulangi dan meningkatkan kesadaran hukum berlalu lintas pengemudi angkot di Makassar, yaitu upaya preventif dan represif.

\section{a. Upaya Preventif}

Dalam rangka menanggulangi terjadinya pelanggaran lalu lintas di Kota Makassar pihak Satlantas Polrestabes Makassar melakukan upaya pencegahan dengan cara melakukan patrol-patroli rutin/oprasi rutin. Kebijakan melakukan patrol tersebut sudah sesuai dengan pasal 14 ayat (1) huruf d undang-undang Nomor 2 tahun 2002 tentang kepolisian negara republik Indonesia, dimana aparat kepolisian harus selalu memelihara ketertiban dan menjamin keamanan umum. Apabila oprasi atau patroli tersebut kurang maksimal maka pihak Satlantas Polrestabes Makassar menggelar oprasi khusus 
lalu lintas. Cara kerja oprasi khusus ini yaitu dengan menggelar razia kendaraan bermotor, baik razia kelengkapan kendaraan bermotor maupun razia surat kendaraan bermotor. Selain itu juga melaksanakan program peningkatan pengetahuan berlalu lintas dalam bentuk kegiatan: polisi sahabat anak, sosialisasi lintas universitas/police go to campus,keamanan berkendara, kampanye keselamatan lalu lintas, pembentukan organisasi terkait lalu lintas serta otomotif, KTL (Kawasan Tertib Lalu Lintas), sekolah mengemudi, dan lain-lain.

\section{b. upaya represif}

Upaya Represif biasanya disertai dengan upaya penerapan paksa. Upaya Represif ialah Tilang, apabila tindak pelanggarannya berat sehingga menimbulkan kecelakaan maka dapat pula diberikan sanksi berupa kurungan penjara sesuai UU Nomor 22 tahun 2009 tentang lalu lintas dan angkutan jalan.

\section{PENUTUP}

\section{A. Kesimpulan}

Berdasarkan data-data yang diperoleh di lapangan dan dari para informan yang telah memberikan keterangan secara rinci kepada penulis tentang yang berkenaan dengan kesadaran hukum berlalu lintas pengemudi angkot-trayek kode $\mathrm{E}$ di Makassar, Setelah data tersebut di analisa secara kualitatif maka dapat ditarik kesimpulan sebagai berikut :

1. Kesadaran hukum berlalu lintas pengemudi angkot-trayek kode E di Makassar masih rendah diukur berdasarkan pengetahuan hukum, pemahaman hukum, sikap hukum dan perilaku hukum yaitu mereka sama sekali tidak mengetahui dan tidak memahami Undang-undang nomor 22 tahun 2009 tentang lalu lintas dan angkutan jalan akan tetapi mereka cenderung mengetahui dan memahami rambu-rambu lalu lintas, namun kurang menghargai dan kurang menaati peraturan tersebut, karena sudah menganggap pelanggaran sebagai kebiasaan, oleh karena itu dapat diketahui bahwa rendahnya kesadaran hukum cenderung karena pelanggaran jadi yang paling dominan mempengaruhi kesadaran hukum berlalu lintas pengemudi angkutan kota trayek kode E di Makassar yaitu perilaku.

2. upaya satlantas polrestabes makassar dalam meningkatkan kesadaran hukum pengemudi angkot yaitu :

a. upaya preventif

Melaksanakan program peningkatan pengetahuan berlalu lintas dalam bentuk kegiatan : polisi sahabat anak, sosialisasi lintas universitas/police go to campus,keamanan berkendara, kampanye keselamatan lalu lintas, pembentukan organisasi terkait lalu lintas serta otomotif, KTL (Kawasan Tertib Lalu Lintas), sekolah mengemudi, dan lain-lain.

b. upaya represif

Upaya Represif biasanya disertai dengan upaya penerapan paksa. Upaya Represif ialah Tilang, apabila tindak pelanggarannya berat sehingga menimbulkan kecelakaan maka dapat pula diberikan sanksi berupa kurungan penjara sesuai UU Nomor 22 tahun 2009 tentang lalu lintas dan angkutan jalan.

\section{B. Saran}

1. Bagi kepolisian,

a. Dalam mewujudkan disiplin dalam tertib berlalu lintas, bahwa setiap pengemudi angkottrayek kode E Makassar Mall-UNM-Perumnas Panakukang harus di siapkan pengetahuan, keterampilan dan sikap, melalui peningkatan pendidikan mengemudi untuk menumbuhkan tingat kesadaran dan kepedulian terhadap tertib lalu lintas.

b. meningkatkan penindakan setiap pelaku pelanggaran dan penyelesaian perkara 
pelanggaran berlalu lintas sesuai dengan proses hukum yang berlaku.

2. Bagi masyarakat

Dalam pembinaan tata tertib berlalu lintas tidak dapat di atasi oleh aparat saja namun di sertai juga adanya kesadaran untuk lebih berdisiplin dan kemauan masyarakat khususnya pengemudi angkot untuk mau merubah situasi lalu lintas yang lebih baik, sehingga upaya peningkatan pelayanan umum penertibannya dapat tercapai.

3. Bagi Pemerintah

Pemerintah harus lebih mengutamakan dalam perlengkapan sarana transportasi dalam pelaksanaan berlalu lintas, seperti halte yang harus disediakan untuk masyarakat sehingga dalam proses pengambilan penumpang dan penurunannya lebih teratur.

\section{DAFTAR PUSTAKA}

A. harvis Zubair. (1995) kuliah etika. Jakarta : PT. Raja Gravindo Persada

A.W. Widjaya (1984), kesadaran hukum manusia dan manusia pancasila. Jakarta : Era swasta

Adib Bohari,(2010),Tanya jawab aturan wajib berlalu lintas,jakarta : pustaka yustisia

Djahiri A.K. (1985), strategi pengajaran efektifnilai moral VCT dan games terhadap VCT.Bandung : jurusan PMPKN FPIPS IKIP Bandung

Darwis, Renidar (2003), pendidikan hukum dalam konteks social budaya bagi pembinaan kesadaran hukum warganegara. Bandung : Universitas pendidikan Indonesia

Kansil, C.S.T.(1984), pengantar ilmu hukum dan tata hukum indonesia.Jakarta : Balai Pustaka

Pedoman penulisan skripsi, fakultas ilmu sosial : universitas negeri Makassar

Lexy j. Moleong (1985). Metodologi penelitian kualitatif. Bandung :PT Remaja Rosada Karya, Bandung

Mertokusumo, s (1986). Mengenal hukum suatu pengantar. Yogyakarta : liberty

Margin. F. suseno (1991), Etika Dasar. Yogyakarta :Kanisius

Otje Salman (1993), beberapa aspek sosiologi hukum, Bandung : alumni
Soerjono Soekanto,(1982), kesadaran hukum dan kepatuhan hukum. Jakarta : cv. Rajawali

Soerjono soekanto, (1983), beberapa aspek sosio yuridis masyarakat, ( bandung : Alumni)

Soerjono soekanto, (1985), factor-faktor yang mempengaruhi penegakan hukum. Jakarta : Rajawali Pers

Sudikno mertokusumo, 1981, meningkatkan kesadaran hukum masyarakat, Yogyakarta : liberty

Taneko, S (1993), pokok-pokok studi hukum dalam masyarakat. Jakarta :Raja Grafindo Persada

http://Repository.upi.edu/operator/upload/s_pkn _0703763

wirawan f, (2006), menumbuhkan disiplin lalu lintas banyak yang harus dibenahi.[online].Tersedia : http://inoshadoww.multply.com/jurnal/item/64[ 07 januari 2016] C

http://repository.upi.edu/operator/upload/s_pkn_ 0703763

\section{UNDANG-UNDANG}

UUD NRI Tahun 1945

Undang-undang Nomor 22 tahun 2009 Tentang Lalu Lintas dan Angkutan jalan, Yogyakarta : Pustaka Mahardika

\section{KUHP}

